\title{
A COMPARATIVE UNIT COST ANALYSIS OF ECHOCARDIOGRAPHY SERVICE BETWEEN ACTIVITY-BASED COSTING, INA-CBGs, AND HOSPITAL CHARGE AT MUHAMMADIYAH YOGYAKARTA HOSPITAL
}

\author{
Kusumawardhani Nindya, Firman Pribadi
}

Masters Program in Hospital Management, Universitas Muhammadiyah Yogyakarta

\begin{abstract}
Background: All countries allocate a portion of resources to the health sector. Under the National Health Insurance (NHI, JKN), tariffs of hospital care service are pre-determined by the Indonesian Case Base Groups (INA-CBGs) payment scheme. Anecdotal evidence reported that there often occurred some discrepancy between hospital charge and INA-CBGs tariff for a specified hospital care service. This gap may cause either loss or excess profit to the hospital. This study aimed to estimate and compare the unit costs of providing echocardiography service using Activity Based Costing (ABC) method, hospital charge, and INA-CBGs tariff, respectively, at Muhammadiyah Yogyakarta Hospital.

Subjects and Method: This was a cost analysis conducted at Muhammadiyah Yogyakarta Hospital, Yogyakarta. A sample of patients aged $\geq 45$ years who used echocardiography was selected for this study. The dependent variable was unit cost of echocardiography. The independent variable was costing method (ABC, hospital charge, and INA-CBGs tariff). The data were obtained from the financial management of the hospital.

Results: The estimated unit costs of echocardiography using ABC method, hospital charge, and INA-CBGs were Rp309.370, Rp343.000, Rp369.500, respectively. The estimated unit cost using ABC method was Rp33.630 lower than hospital charge and Rp 60.130 lower than INA-CBGs tariff.

Conclusion: The unit cost using $\mathrm{ABC}$ method was lower than hospital charge and INA-CBGs tariff. Corrective policy action should be made to fill this gap.

Keywords: echocardiography, unit cost, activity-based costing, hospital charge INA-CBGs tariff

\section{Correspondence:}

Kusumawardhani Nindya. Masters Program in Hospital Management, Universitas Muhammadiyah Yogyakarta, Jl. Lingkar Selatan, Tamantirto, Kasihan, Bantul, Yogyakarta 55183. Email: nindya.apsari.na@gmail.com. Mobile: o89687676224
\end{abstract}

